\title{
GAMBARAN LAJU FILTRASI GLOMERULUS PADA PENDERITA DIABETES MELLITUS TIPE 2 DI RSUD DR. DORIS SYLVANUS PALANGKA RAYA
}

\author{
Fera Sartika ${ }^{1}$, Dwi Purbayanti ${ }^{2}$ Davida Safitri ${ }^{3}$ \\ 1Dosen Program Studi D-III Analis Kesehatan Universitas Muhammadiyah Palangkaraya \\ ${ }^{2}$ Dosen Program Studi D-III Analis Kesehatan Universitas Muhammadiyah Palangkaraya \\ ${ }^{2}$ Mahasiswa Program Studi D-III Analis Kesehatan Fakultas IImu Kesehatan, \\ Universitas Muhammadiyah Palangkaraya \\ e-mail : Sartikafera3@gmail.com
}

\begin{abstract}
ABSTRAK
Diabetes Mellitus (DM) adalah suatu penyakit dimana tingginya kadar glukosa darah yang disebabkan oleh pankreas gagal memproduksi insulin atau terjadinya resistensi insulin. DM digolongkan atas DM tipe 1 dan DM tipe 2. DM tipe 2 yang tidak ditangani dengan baik akan menimbulkan berbagai komplikasi yaitu komplikasi akut dan komplikasi kronis. Komplikasi kronis DM tipe 2 dapat berupa komplikasi mikrovaskular dan makrovaskular. Nefropati diabetik merupakan salah satu komplikasi mikrovaskuler, yaitu komplikasi yang terjadi pada pembuluh darah. Akibat tingginya kadar glukosa dalam darah dapat membuat terganggunya fungsi ginjal. Kemungkinan adanya penurunan fungsi ginjal pada penderita DM dapat diketahui salah satunya dengan penentuan klirens kreatinin. Salah satu indeks fungsi ginjal yang dapat diukur secara tidak langsung dengan perhitungan klirens kreatinin adalah Laju Filtrasi Glomerulus (LFG), dengan menggunakan rumus Formula Corkroft-Gault. Penelitian ini bertujuan untuk mengetahui gambaran laju filtrasi glomerulus pada penderita DM tipe 2 di RSUD dr. Doris Sylvanus Palangka Raya. Penelitian ini menggunakan metode deskriftif untuk menggambarkan laju filtrasi glomerulus pada penderita DM tipe 2. Jumlah sampel yang diperoleh adalah 41 orang.

Simpulan: Hasil penelitian berdasarkan rumus Formula Corkroft-Gault menunjukkan LFG normal $10 \%$, Penurunan ringan LFG 15\%, Penurunan moderat LFG 70\%, Penurunan berat LFG 5\%, dan Gagal ginjal 0\%
\end{abstract}

Kata kunci: Kadar ALT, Pengonsumsi Minuman Beralkohol

\section{PENDAHULUAN}

Menurut World Health Organization (WHO), Diabetes Mellitus (DM) adalah suatu penyakit dimana tingginya kadar glukosa darah yang disebabkan oleh pankreas gagal memproduksi insulin atau terjadinya resistensi insulin (Aveonita, 2015). DM digolongkan atas DM tipe 1 dan DM tipe 2 (Fadhilah, 2016).
Menurut WHO Indonesia menempati urutan keempat didunia sebagai penyandang DM terbanyak setelah India, China, dan Amerika. Bahkan WHO memprediksi terjadinya kenaikan jumlah pasien diabetes dari 8,4 juta pada tahun 2000 menjadi sekitar 21,3 juta pada tahun 2030 mendatang (Aini et. al, 2011). Dan Menurut data rekam medik di RSUD dr, Doris Sylvanus Palangka Raya pada 
tahun 2015, diketahui jumlah pasien Diabetes Mellitus Tipe 1 sebanyak 244 orang dan Diabetes tipe 2 sebanyak 916 orang.

DM tipe 2 yang tidak ditangani dengan baik akan menimbulkan berbagai komplikasi yaitu komplikasi akut dan komplikasi kronis. Komplikasi kronis DM tipe 2 dapat berupa komplikasi mikrovaskular dan makrovaskular. komplikasi makrovaskular seperti pembuluh darah koroner, pembuluh darah otak dan pembuluh darah perifer. Sedangkan komplikasi Mikrovaskular yaitu komplikasi terjadi pada pembuluh darah, merupakan lesi spesifik diabetes yang menyerang kapiler dan arteriola retina (retinopati diabetik), glomerulus ginjal (nefropati diabetik) dan saraf - saraf perifer (neuropati diabetic) (Edwina et.,al, 2015)

Nefropati diabetik (ND) merupakan salah satu komplikasii DM yang dapat menyebabkan gagall ginjal tahap akhir. (Markum \& Galastri, 2004). Sekitar 40\% pasien DM dapat berkembang menjadi ND atau gangguan pada filtrasi glome glomerulus (GFR) dan ditandaii dengan albuminuria menetap yaitu > $300 \mathrm{mg} / 24$ jam, pada minimal dua kali pemeriksaan dalam kurun waktu 3 sampai 6 bulan (Putri, 2015; De Boer et al, 2011).

Jumlah pasien DM tipe 2 lebih banyak dibandingkan DM tipe 1, sehingga angka kejadian ND pada DM tipe 2 lebih besar dibandingkan DM tipe 1 (Putri, 2015). Salah satu Pemeriksaan yang dapat dilakukan untuk mengetahui kemungkinan adanya penurunan fungsi ginjal pada penderita DM adalah dengan penentuan klirens kreatinin (Sudoyo, 2010).

Salah satu indeks fungsi ginjal yang dapat diukur secara tidak langsung dengan perhitungan klirens kreatinin adalah Laju Filtrasi Glomerulus (LFG). Laju filtrasi glomerulus adalah volume darah yang dibersihkan dari suatu zat dengan eksresi dalam urin dalam waktu 1 menit (sudoyo, 2015).

\section{METODE PENELITIAN}

Jenis penelitian yang digunakan adalah deskriptif yaitu suatu metode penelitian yang dilakukan dengan tujuan untuk mendeskripsikan atau menjelaskan suatu peristiwa. Lokasi penelitian dilakukan di Laboratorium Patologi Klinik RSUD dr. Doris Sylvanus Palangka Raya. Populasi penelitian adalah keseluruhan dari obyek atau subyek yang diteliti. Populasi dalam penelitian ini adalah pasien rawat jalan yang menderita DM Tipe 2. Pengambilan sampel dilakukan dengan teknik purposive sampling, dimana sampel berdasarkan kriteria yang ditentukan yaitu:

1. Pasien menderita DM tipe 2 lebih dari 2 tahun

2. Melakukan pemeriksaan glukosa puasa, glukosa 2 jam pp (Post Prandial) dan kreatinin di laboratorium patologi klinik RSUD dr. Doris Sylvanus Palangka Raya. 
Jumlah sampel dalam penelitian ini adalah

41 orang.

Pengolahan data meliputii kegiatan penghitungan nilai klirens kreatinin dengan Rumus Cockroft-Gault untuk estimasi klirens kreatinin.

Klirens kreatinin :

Laki-laki $\left.=\frac{(140-\text { umur }) \times B B}{72 \times \text { Kreatinin serum }}\right)$

Perempuan $\left.=\frac{(140-\text { umur }) \times B B}{72 \times \text { Kreatinin serum }}\right) \times(0,85)$

\section{Bahan Penelitian}

Bahan-bahan yang digunakan dalam penelitian ini meliputi: KIT Reagen pemeriksaan glukosa dan kreatinin

\section{Alat penelitian}

Jarum suntik $3 c c$, Torniquet, kapas alkohol 70\%, Fotomoter 5010, sentrifuge, tabung reaksi, Mikropipet, dan Tip (biru dan kuning).

\section{HASIL PENELITIAN}

a. Karakteristik subyek penelitian

1. Tabel 1. Berdasarkan Jenis Kelamin

\begin{tabular}{l|c|c|}
\hline $\begin{array}{c}\text { Jenis } \\
\text { Kelamin }\end{array}$ & $\mathbf{N}$ & Persentase \\
\hline Laki-Laki & 18 & $44 \%$ \\
Perempuan & 23 & $56 \%$ \\
Jumlah & 41 & $100 \%$ \\
\hline
\end{tabular}

Dari Tabel 1 diatas diperoleh hasil bahwa frekuensi penderita diabetes mellitus tipe 2 banyak diderita oleh perempuan sebesar $56 \%$ sedangkan laki-laki sebesar $44 \%$

b. Hasil perhitungan terhadap subyek penelitian berdasarkan variabel penelitian

Tabel 1. Profil Diabetes Mellitus Tipe 2 Berdasarkan klirens kreatinin

\begin{tabular}{lcc|}
\hline \multicolumn{1}{c}{$\begin{array}{c}\text { Klirens Kreatinin } \\
\text { (mL/menit) }\end{array}$} & Jumlah & Persentase \\
\hline LFG Normal & 4 & $10 \%$ \\
Penurunan ringan LFG & 6 & $15 \%$ \\
Penurunan Moderat LFG & 29 & $70 \%$ \\
Penurunan Berat LFG & 2 & $5 \%$ \\
Gagal Ginjal & 0 & $0 \%$ \\
\multicolumn{1}{c}{ Jumlah } & 41 & $100 \%$ \\
\hline
\end{tabular}

Dari Tabel 2 menunjukkan bahwa hasil klirens kreatinin paling banyak mengalami Penurunan Moderat LFG dengan persentase $70 \%$ dengan jumlah penderita 29 orang dan Penurunan ringan LFG memiliki persentase 15\% dengan jumlah penderita 6 orang. 
Gambaran Laju Filtrasi Glomerulus Pada Penderita Diabetes Mellitus Tipe 2 Di RSUD Dr.

Tabel 3. Profil Klirens Kreatinin Berdasarkan Kreatinin Serum

\begin{tabular}{|c|c|c|c|c|c|c|c|c|c|c|c|c|}
\hline \multirow{3}{*}{$\begin{array}{c}\text { Kreatinin } \\
\text { Serum }\end{array}$} & \multicolumn{10}{|c|}{ Klirens Kreatinin } & \multicolumn{2}{|c|}{ Jumlah } \\
\hline & \multicolumn{2}{|c|}{ Normal } & \multicolumn{2}{|c|}{ PR } & \multicolumn{2}{|c|}{ PM } & \multicolumn{2}{|c|}{ PB } & \multicolumn{2}{|c|}{ GG } & & \\
\hline & $\mathbf{N}$ & $\%$ & $\mathbf{N}$ & $\%$ & $\mathbf{N}$ & $\%$ & $\mathbf{N}$ & $\%$ & $\mathbf{N}$ & $\%$ & $\mathbf{N}$ & $\%$ \\
\hline Tinggi & 0 & 0 & 0 & 0 & 12 & 29 & 2 & 5 & 0 & 0 & 14 & 34 \\
\hline Normal & 3 & 7 & 6 & 15 & 17 & 41 & 0 & 0 & 0 & 0 & 26 & 63 \\
\hline Rendah & 1 & 3 & 0 & 0 & 0 & 0 & 0 & 0 & 0 & 0 & 1 & 3 \\
\hline Jumlah & 4 & 10 & 6 & 15 & 29 & 70 & 2 & 5 & 0 & 0 & 41 & $100 \%$ \\
\hline
\end{tabular}

Ket: PR (Penurunan ringan LFG), PM (Penurunan Moderat LFG), PB

(Penurunan Berat LFG), GG (Gagal Ginjal)

Tabel 3 menunjukkan bahwa berdasarkan kadar kreatinin serum yang meningkat memiliki persentase $34 \%$ dengan jumlah 14 orang, dengan kategori klirens kreatinin penurunan moderat LFG $29 \%$ dengan jumlah 12 orang dan penurunan berat LFG $5 \%$ sebanyak 2 orang. Pada kadar kreatinin normal memiliki persentase $63 \%$ dengan jumlah pasien 26 orang, dengan kategori klirens kreatinin penurunan ringan LFG 15\% sebanyak 6 orang dan penurunan moderat LFG $41 \%$ sebanyak 17 orang. Pada kreatinin serum menurun memiliki $3 \%$ sebanyak 1 orang dengan kategori klirens kreatinin normal. 3. Tabel 4. Profil Diabetes Mellitus Tipe 2 Berdasarkan Lama Menderita Diabetes Mellitus Tipe 2

\begin{tabular}{|c|c|c|c|c|c|c|c|c|c|c|c|c|}
\hline \multirow{3}{*}{$\begin{array}{c}\text { Lama } \\
\text { Menderira } \\
\text { DM Tipe } 2\end{array}$} & \multicolumn{10}{|c|}{ Klirens Kreatinin } & \multicolumn{2}{|c|}{ Jumlah } \\
\hline & \multicolumn{2}{|c|}{ Normal } & \multicolumn{2}{|c|}{ PR } & \multicolumn{2}{|c|}{ PM } & \multicolumn{2}{|c|}{ PB } & \multicolumn{2}{|c|}{ GG } & & \\
\hline & $\mathbf{N}$ & $\%$ & $\mathbf{N}$ & $\%$ & $\mathbf{N}$ & $\%$ & $\mathbf{N}$ & $\%$ & $\mathbf{N}$ & $\%$ & $\mathbf{N}$ & $\%$ \\
\hline $3-5$ & 4 & 9 & 6 & 15 & 26 & 63 & 0 & 0 & 0 & 0 & 3 & 87 \\
\hline $6-7$ & 0 & 0 & 0 & 0 & 3 & 7 & 1 & 2 & 0 & 0 & 4 & 11 \\
\hline $8-9$ & 0 & 0 & 0 & 0 & 0 & 0 & 1 & 2 & 0 & 0 & 1 & 2 \\
\hline Jumlah & 4 & 12 & 6 & 14 & 29 & 70 & & 4 & 0 & 0 & 41 & 10 \\
\hline
\end{tabular}

Ket: PR (Penurunan ringan LFG), PM (Penurunan Moderat LFG), PB (Penurunan Berat LFG), GG (Gagal Ginjal)

Tabel 4. menunjukkan bahwa penderita mengidap diabetes mellitus tipe 2 dengan lama 3-5 tahun memiliki persentase sebanyak $87 \%$ dengan jumlah pasien 36 orang, dengan kategori normal $9 \%$ sebanyak 4 orang, penurunan ringan 
LFG $15 \%$ sebanyak 6 orang, penurunan moderat LFG $63 \%$ sebanyak 26 orang. Diabetes mellitus tipe 2 dengan lama 6-7 tahun memiliki presentase $11 \%$ penurunan moderat LFG $7 \%$ sebanyak 3 orang, penurunan berat LFG $2 \%$ sebanyak 1 orang 8-9 tahun memiliki persentase $2 \%$ sebanyak 1 orang dengan kategori klirens kreatinin penurunan berat LFG yaitu $2 \%$ sebanyak 1 orang.

4. Tabel 5. Profil Pasien Diabetes Mellitus Tipe 2 Bedasarkan Berat Badan

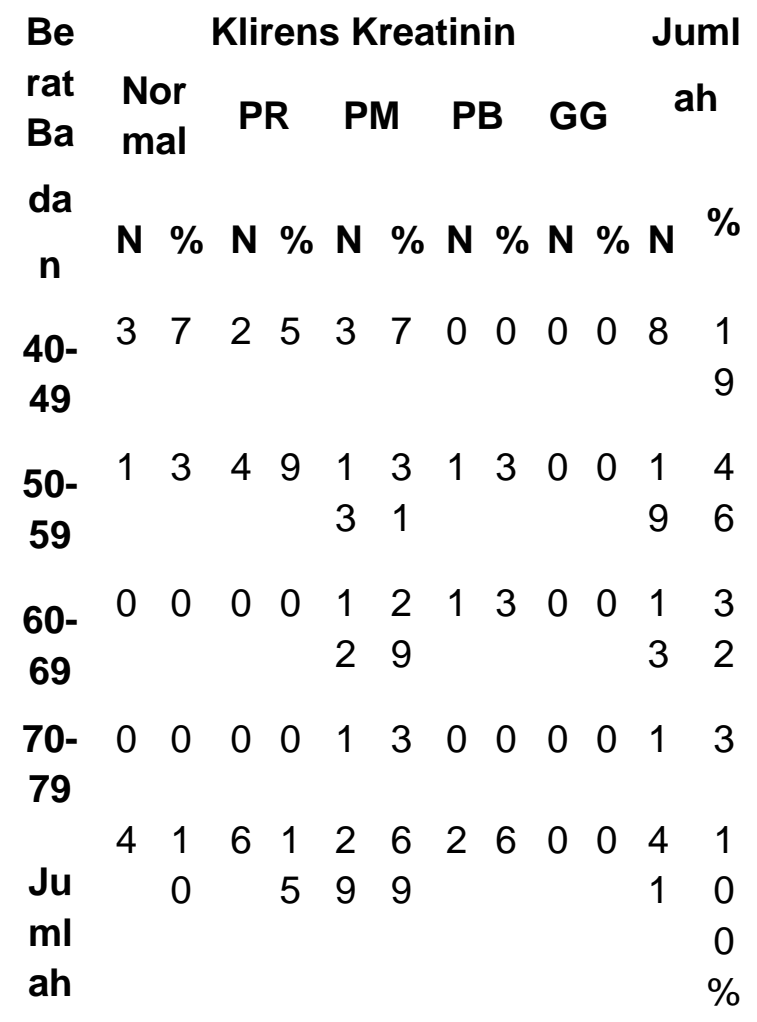

Ket: PR (Penurunan ringan LFG), PM (Penurunan Moderat LFG), PB (Penurunan Berat LFG), GG (Gagal Ginjal)

Tabel 5 menunjukkan bahwa pada berat badan 40-49 memiliki persentase
9\% dengan jumlah pasien sebanyak 8 orang, dengan kategori normal 7\% sebanyak 3 orang, dengan kategori penurunan ringan LFG $5 \%$ sebanyak 2 orang dan kategori penurunan moderat LFG $7 \%$ sebanyak 3 orang. Pada berat badan 50-59 memiliki persentase $46 \%$ dengan jumlah pasien sebanyak 19 orang, dengan kategori normal $3 \%$ sebanyak 1 orang, dengan kategori penurunan ringan LFG $9 \%$ sebanyak 4 orang, dengan kategori penurunan moderat LFG 31\% sebanyak 13 orang dan kategori penurunan berat LFG $3 \%$ sebanyak 1 orang. Pada berat badan 60-69 memiliki persentase $32 \%$ dengan jumlah pasien sebanyak 13 orang, dengan kategori penurunan moderat LFG $29 \%$ sebanyak 12 orang, dan kategori gagal ginjal 3\% sebanyak 1 orang. Pada berat badan 7079 memiliki persentase $3 \%$ dengan jumlah pasien 1 orang, dengan kategori penurunan moderat LFG $3 \%$ sebanyak 1 orang. 5. Tabel 6. Profil Pasien Diabetes Mellitus Tipe 2 Berdasarkan Usia 


\begin{tabular}{|c|c|c|c|c|c|c|c|c|c|c|c|c|}
\hline \multirow{3}{*}{ Usia } & \multicolumn{10}{|c|}{ Klirens Kreatinin } & \multirow{2}{*}{\multicolumn{2}{|c|}{ Jumlah }} \\
\hline & \multicolumn{2}{|c|}{ Normal } & \multicolumn{2}{|c|}{ PR } & \multicolumn{2}{|c|}{ PM } & \multicolumn{2}{|c|}{ PB } & \multicolumn{2}{|c|}{ GG } & & \\
\hline & $\mathbf{N}$ & $\%$ & $\mathbf{N}$ & $\%$ & $\mathbf{N}$ & $\%$ & $\mathbf{N}$ & $\%$ & $\mathbf{N}$ & $\%$ & $\mathbf{N}$ & $\%$ \\
\hline $40-49$ & 2 & 5 & 2 & 5 & 6 & 15 & 0 & 0 & 0 & 0 & 10 & 2 \\
\hline $50-59$ & 1 & 2 & 4 & 10 & 13 & 32 & 0 & 0 & 0 & 0 & 18 & 44 \\
\hline $60-69$ & 1 & 2 & 0 & 0 & 10 & 24 & 2 & 5 & 0 & 0 & 13 & 31 \\
\hline Jumlah & 4 & 9 & 6 & 15 & 29 & 71 & 2 & 5 & 0 & 0 & 41 & $100 \%$ \\
\hline
\end{tabular}

Ket: PR (Penurunan ringan LFG), PM (Penurunan Moderat LFG), PB (Penurunan Berat LFG), GG (Gagal Ginjal)

Tabel 6 menunjukkan bahwa pada usia 40-49 tahun memiliki persentase $2 \%$ dengan jumlah pasien sebanyak 10 orang, dengan kategori klirens kreatinin normal $5 \%$ sebanyak 2 orang, dengan kategori penurunan ringan LFG $5 \%$ sebanyak 2 orang dan penurunan moderat LFG $15 \%$ sebanyak 6 orang. Pada usia 50-59 tahun memiliki persentase $44 \%$ sebanyak 18 orang, dengan kategori normal $2 \%$ sebanyak 1 orang, dengan kategori penurunan ringan LFG $10 \%$ sebanyak 4 orang, dan kategori penurunan moderat LFG $32 \%$ sebanyak 13 orang. Pada usis 60-69 tahun memiliki persentase 31\% sebanyak 13 orang, dengan kategori normal $2 \%$ sebanyak 1 orang dan kategori penurunan moderat LFG $24 \%$ sebanyak 10 orang.

\section{PEMBAHASAN}

Penelitian klirens kreatinin pada pasien diabetes mellitus tipe 2 dilakukan pada tanggal 18 Mei - 18 Juni 2017 di laboratorium Patologi Klinik RSUD dr. Doris Sylvanus Palangkaraya. Pengambilan sampel adalah pasien diabetes mellitus tipe 2 yang telah menderita lebih dari 2 tahun dan rutin memeriksa ke laboratorium, dengan sampel yang berjumlah 41 sampel dimana sampel terdiri dari 18 laki-laki dan 23 perempuan.

Pada penelitian ini menggunakan teknik purposive sampling, dimana dilakukan pengambilan sampel berdasarkan kriteria yang diketahui oleh peneliti, sebelum dilakukan perhitungan klirens kreatinin, dilakukan wawancara terhadap pasien berapa lama menderita diabetes mellitus tipe 2 serta penimbangan berat badan untuk melengkapi data kemudian dilakukan pengambilan darah dan pemeriksaan kreatinin, dari hasil pemeriksaan kreatinin kemudian dihitung menggunakan perhitungan Formula Cockroft-Gault.

Pada tabel 1. Profil diabetes melitus tipe 2 berdasarkan jenis kelamin dari total 41 pasien diabetes mellitus tipe 2 
terdapat laki-laki dengan jumlah 18 orang dan perempun berjumlah 23 orang, baik laki-laki maupun perempuan memiliki risiko yang sama besar untuk mengidap penyakit diabetes mellitus khususnya tipe 2, hanya saja dilihat dari faktor risiko perempuan mempunyai peluang lebih besar diakibatkan peningkatan indeks massa tubuh yang lebih besar. Sindroma siklus bulanan pasca menopause yang membuat distribusi lemak tubuh menjadi mudah terakumulasi akibat proses hormonal tersebut sehingga wanita berisiko menderita diabetes mellitus (Kwang, et al., 2012)

Pada tabel 2. Menunjukkan kemungkinan terjadinya komplikasi nefropati diabetik, karena data yang terlihat dengan jumlah 41 pasien DM tipe 2 mengalami penurunan glomerulus dengan persentase 95\%, dan $70 \%$ mengalami penurunan moderat. Sehingga menunjukkan terjadinya komplikasi atau gangguan pada fungsii ginjal. Hal ini mungkin dikarenakan akibat tingginya glukosa darah sehingga dapat menyebabkan kerusakan pada pembuluh darah halus di ginjal, rusaknya pembuluh darah ini diakibatkan oleh hipertensi. Sesangkan, glukosa darah yang tinggi dapat menyebabkan penebalan membran basal dan pelebaran glomerulus (Corwin, 2009).

Pada tabel 3. menunjukkan kadar kreatinin serum normal namun pengukuran klirens kreatinin menurun. Hal ini dikarenakan kreatinin serum merupakan hasil akhir metabolisme otot. Hubungan antara kreatinin serum dan LFG penting karenai penurunan LFG yang signifikan dapat terjad i sebelum terjadinya kenaikan kreatinin serum, sehingga dapat digunakan metode pengukuran LFG lain yang lebih akurat seperti pengumpulan urin 24 jam. Dimana, urin 24 jam dapat digunakan untuk mengetahui terjadinya gangguan pada fungsi ginjal pada pasien diabetes mellitus dengan komplikas i penyakit ginjal mempunyai prevalensi proteinuria yang tinggi, (National Kidney Foundation, 2007).

Pada tabel 4. menunjukkan berdasarkan lamanya menderita diabetes mellitus pada penelitian ini didapatkan nilai klirens kreatinin dengan kerusakan ginjal dengan penurunan moderat LFG diperoleh sekitar 87\%, semakin lama pasien menderita diabetes mellitus tipe 2 maka dikhawatirkan akan mengalami komplikasi. Salah satu. Komplikasi yang terjadi adalah nefropati diabetika (Soegondo, et al., 2002).

Pada tabel 5. menunjukkan berdasarkan berat badan diperoleh klirens kreatinin yang paling banyak mengalami penurunan adalah dengan berat badan 50-59 $\mathrm{kg}$ dimana terjadi penurununan moderat LFG sebanyak 13 orang (31\%). Hal ini mungkin disebabkan karena formula Cockroft-Gault salah satu pengalinya adalah berat badan, dimana dapat dipengaruhi oleh massa otot sehingga semakin kecil berat badan semakin sedikit nila i klirens kreatininnya. 
Gambaran Laju Filtrasi Glomerulus Pada Penderita Diabetes Mellitus Tipe 2 Di RSUD Dr. Doris Sylvanus Palangka Raya

Pada tabel 6. menunjukkan
berdasarkan usia diperoleh klirens kreatinin yang didapat pada rentang usia 40-49 tahun mengalami penurunan fungsi ginjal dengan persentase $2 \%$, pada usia 50-69 tahun terjadi penurunan fungsi ginjal yang lebih cepat dengan persentase 44\%, LFG menurun secara bertahap seiring bertambahnya usia, bahkan pada orang tanpa penyakit ginjall (National Kidney Foundation, 2007).

\section{KESIMPULAN}

Hasil penelitian berdasarkan rumus Formula Corkroft-Gaul dari 41 orang penderita DM tipe 2, menunjukkan LFG normal $10 \%$, Penurunan ringan LFG $15 \%$, Penurunan moderat LFG 70\%, Penurunan berat LFG 5\%, dan Gagal ginjal 0\%

\section{DAFTAR PUSTAKA}

1. Aveonita Rhana Agatha.Rr, 2015. Effect of Aloe vera in lowering blood glucose levels on Diabetes Melitus. Faculty of Medicine, Lampung University. Article review J MAJORITY, 4(2): pp 104

2. Aini Nur, Fatmaningrum widarti, Yusuf $\mathrm{AH}$. 2011. Changing the patient's behavior in diabetes melitus management by application Dorothy E.Johnson's behavioral system model. Jurnal Ners; 6(1): 1-10.

3. Corwin, E.J. 2009. Buku Saku Patofisiologi. Jakarta: EGC.

4. De Boer I.H, Rue TC, Hall YN, Heagerty PJ, Weiss NS, Himmelfarb J. 2011.
Temporal Trends in The Prevalence of Diabetic Kidney Disease in The Unites States. Journal of the American Medical Association. 305:2532-39

5. Edwina A.D, Manaf Asman, Efrida. 2015. Pola Komplikasi Kronis Penderita Diabetes Melitus

Tipe 2 Rawat Inap di Bagian Penyakit Dalam RS. Dr. M. Djamil Padang Januari 2011. Jurnal Kesehatan Andalas. 4(1) pp 103

6. Fadhilah, A.F. 2016. Hubungan Antara Penurunan Laju Filtrasi Glomerulus Dengan Berat Anemia Pada Pasien Nefropati Diabetik di RSUD DR. Sayidiman Magetan. Skripsi. FK UMS.

7. Kwang-Wen Chen, Tseng min hsu, Huang3 Yao Yu and Chuang Jue-Yuh. 2012. The Barriers to Initiating Insulin Therapy among People with Type 2 Diabetes in Taiwan - A Qualitative Study. J Diabetes Metab: 3(5)

8. Markum H.M.S., Galastri M., 2004. Diabetic Nephropathy AmongType 2 Diabetes Mellitus Patients in Dr. Cipto Mangunkusumo Hospital. Medical Journal of Indonesia. 13:161-5

9. National Kidney Foundation. KDOQI. 2007. clinical practice guidelines on and clinical practice recommendations for diabetes and chronic kidney disease. Am J Kidney Dis.

10.Putri Isya Rahmadany. 2015. Diabetic Nephropathy Determinant Factor in Diabetes Mellitus at RSUD Dr. M. 
Fera Sartika' Dwi Purbayanti dan Davida Safitri

Soewandhie Surabaya. Jurnal Berkala

Epidemiologi, 3(1) pp 109-121

11.Soegondo, Sidartawan, dan Pradana.

2002. Penatalaksanaan Diabetes

Mellitus Terpadu. Jakarta: FKUI.

12. Sudoyo, Aru, W. dkk. 2006. IImu

Penyakit Dalam.Jakarta: FKUI 